\title{
PENGARUH EARNINGS, CASH FLOW FROM OPERATIONS, WORKING CAPITAL FROM OPERATIONS, DAN ACCRUAL COMPONENTS TERHADAP FUTURE CASH FLOW PADA PERUSAHAAN MANUFAKTUR YANG TERDAFTAR DI BURSA EFEK INDONESIA
}

\author{
Sofia Prima Dewi dan Venny Gunawan \\ Fakultas Ekonomi Universitas Tarumanagara Jakarta \\ Email: sofia_primadewi@yahoo.com
}

\begin{abstract}
The purpose of this study was to obtain empirical evidence about the effect of earnings, cash flow from operations, working capital from operations, and accrual components to future cash flow in manufacturing companies listed in Indonesia Stock Exchange. The samples used were 165 manufacturing companies listed in Indonesia Stock Exchange during 2010-2012. Data analysis was performed with the aid of a software program Statistical Product and Service Solutions (SPSS) for Windows. The results showed that earnings, cash flow from operations, and working capital from operations have an influence on future cash flow, while accrual components does not have any influence on future cash flow.
\end{abstract}

Key words: future cash flow, earnings, cash flow from operations, working capital from operations, accrual components

\begin{abstract}
Abstrak: Tujuan penelitian ini adalah untuk mendapatkan bukti empiris mengenai pengaruh earnings, cash flow from operations, working capital from operations, dan accrual components terhadap future cash flow pada perusahaan manufaktur yang terdaftar di Bursa Efek Indonesia. Sampel yang digunakan adalah 165 perusahaan manufaktur yang terdaftar di Bursa Efek Indonesia selama tahun 2010-2012. Analisis data dilakukan dengan bantuan program software Statistical Product and Service Solution (SPSS) for Windows. Hasil penelitian menunjukkan bahwa earnings, cash flow from operations, dan working capital from operations memiliki pengaruh terhadap future cash flow, sedangkan accrual components tidak memiliki pengaruh terhadap future cash flow.
\end{abstract}

Kata kunci: future cash flow, earnings, cash flow from operations, working capital from operations, accrual components

\section{PENDAHULUAN}

Sektor industri manufaktur merupakan komponen utama penggerak perekonomian nasional. Tingkat persaingan dalam dunia bisnis semakin tajam, tidak terkecuali di sektor industri manufaktur di Indonesia. Setiap perusahaan dituntut untuk selalu meningkatkan kinerjanya agar dapat bertahan dalam persaingan. Kinerja perusahaan yang baik dapat dilihat melalui laporan keuangan. Menurut Ikatan Akuntan Indonesia (2012: 5) laporan keuangan merupakan catatan informasi keuangan suatu perusahaan pada suatu periode akuntansi yang bertujuan untuk menyediakan informasi yang bermanfaat bagi para pengguna laporan dalam mengambil keputusan. Perusahaan harus menyusun dan 
menyajikan laporan arus kas sebagai bagian yang tak terpisahkan dari laporan keuangan untuk setiap periode penyajian laporan keuangan. Laporan arus kas merupakan salah satu informasi yang penting bagi para pengguna laporan keuangan dalam mengambil keputusan karena laporan tersebut menggambarkan kemampuan perusahaan dalam menghasilkan arus kas masuk dan arus kas keluar selama satu periode tertentu. Informasi yang terdapat dalam laporan arus kas juga dapat digunakan sebagai dasar untuk memprediksi future cash flow. Future cash flow adalah arus kas operasi perusahaan di masa yang akan datang yang diharapkan mampu berkembang dengan baik sesuai dengan prediksi yang telah dilakukan sebelumnya.

Penelitian mengenai faktor-faktor yang mempengaruhi future cash flow telah banyak dilakukan, tetapi terdapat ketidakkonsistenan atas hasil penelitian. Penelitian Takhtaei dan Karimi (2013), Moeinaddin, et al. (2012), serta Joni (2011) menunjukkan bahwa earnings memiliki pengaruh terhadap future cash flow, tetapi penelitian Yuliafitri (2011) menunjukkan bahwa earnings tidak memiliki pengaruh terhadap future cash flow. Penelitian Takhtaei dan Karimi (2013) serta Joni (2011) menunjukkan bahwa cash flow from operations memiliki pengaruh terhadap future cash flow, tetapi penelitian Moeinaddin, et al. (2012) serta Yuliafitri (2011) menunjukkan bahwa cash flow from operations tidak memiliki pengaruh terhadap future cash flow.

Penelitian Takhtaei dan Karimi (2013) menunjukkan bahwa working capital from operations memiliki pengaruh terhadap future cash flow, tetapi penelitian Moeinaddin, et al. (2012) menunjukkan bahwa working capital from operations tidak memiliki pengaruh terhadap future cash flow. Penelitian Shubita (2013) menunjukkan bahwa accrual components memiliki pengaruh terhadap future cash flow, tetapi penelitian Tanri, et al. (2014) menunjukkan bahwa accrual components tidak memiliki pengaruh terhadap future cash flow. Ketidakkonsistensian hasil-hasil penelitian di atas menjadi latar belakang untuk dilakukannya kembali penelitian mengenai pengaruh earnings, cash flow from operations, working capital from operations, dan accrual components terhadap future cash flow pada perusahaan manufaktur yang terdaftar di Bursa Efek Indonesia selama tahun 2010-2012.

\section{KAJIAN TEORI}

Future Cash Flow. Menurut Ikatan Akuntan Indonesia (2012: 2.1) informasi yang tersedia dalam laporan arus kas dapat digunakan oleh para pengguna laporan untuk mengevaluasi perubahan aktiva bersih perusahaan, struktur keuangan, dan kemampuan untuk mempengaruhi jumlah serta waktu arus kas dalam rangka adaptasi dengan perubahaan keadaan dan peluang. Selain itu, informasi ini juga dapat digunakan untuk mengevaluasi kemampuan perusahaan dalam menghasilkan arus kas di masa yang akan datang dan membandingkannya dengan kewajiban jangka pendek maupun jangka panjang. Arus kas masa depan merupakan arus kas operasi perusahaan di masa yang akan datang atau di periode berikutnya yang diharapkan mampu berkembang dengan baik sesuai dengan prediksi yang telah dilakukan sebelumnya.

Menurut Ikatan Akuntan Indonesia (2012: 2.2):

"Informasi arus kas historis sering digunakan sebagai indikator dari jumlah, waktu, dan kepastian arus kas masa depan. Di samping itu, informasi arus kas historis juga berguna untuk meneliti kecermatan dari taksiran arus kas masa 
depan yang telah dibuat sebelumnya dan dalam menentukan hubungan antara profitabilitas dan arus kas neto serta dampak perubahan harga."

Arus kas masa depan adalah keadaan arus kas operasi suatu perusahaan pada suatu periode yang merupakan realisasi dari usaha masa lalu yang sebelumnya telah diprediksi dengan menggunakan data historis. Prediksi arus kas masa depan dengan menggunakan data historis berguna untuk mengurangi ketidakpastian, mengukur risiko yang mungkin terjadi di masa depan, serta sebagai alat untuk melakukan evaluasi. Prediksi yang dilakukan juga diharapkan dapat memberikan perencanaan yang lebih baik sehingga perusahaan akan memperoleh keuntungan yang lebih besar jika dibandingkan dengan tahun sebelumnya. Bagi para pengguna laporan keuangan, prediksi arus kas dapat digunakan untuk menilai kemampuan perusahaan dalam menghasilkan kas dan setara kas, memprediksi kesulitan keuangan, menilai kinerja manajemen, serta memberikan gambaran mengenai aliran kas masuk yang diharapkan dan aliran kas keluar untuk periode yang akan datang.

Earnings. Earnings (laba) adalah selisih antara pendapatan dan biaya yang dikeluarkan. Menurut Wanti (2012: 36):

"Laba dapat digunakan sebagai alat untuk mengukur kinerja perusahaan serta memberikan informasi yang berkaitan dengan kewajiban manajemen atas tanggungjawabnya dalam pengelolaan sumber daya yang telah dipercayakan kepadanya. Informasi laba diterbitkan oleh manajemen yang lebih mengetahui kondisi di dalam perusahaan. Informasi tentang kinerja perusahaan, terutama tentang profitabilitas dibutuhkan untuk membuat keputusan tentang sumber ekonomi yang akan dikelola perusahaan di masa yang akan datang."

Laba dapat dijadikan parameter untuk menilai kinerja suatu perusahaan. Kinerja perusahaan yang digambarkan melalui pelaporan laba di setiap periode dapat mengindikasikan kemampuan laba perusahaan dalam menghasilkan kas di periode tersebut. Laba juga sering dijadikan dasar oleh para pengguna laporan keuangan untuk mengambil keputusan ekonomi seperti menentukan kebijakan dividen, sebagai dasar pengenaan pajak, dasar untuk menentukan besarnya laba per lembar saham, sebagai pedoman untuk berinvestasi, serta dapat digunakan untuk mengukur keberhasilan atau kegagalan suatu perusahaan pada masa yang akan datang. Hal ini dikarenakan laba dapat memberikan informasi yang potensial yang dapat membantu dalam mengevaluasi peristiwa masa lalu, masa kini, maupun masa depan.

Menurut Pratiwi (2010: 2) laba dapat menggambarkan keadaan perusahaan secara menyeluruh dan keberhasilan operasi perusahaan selama satu periode tertentu, karena laba berasal dari unsur-unsur penghasilan dan beban yang berhubungan dengan aktivitas operasi perusahaan. Menurut Joni (2011: 39) laba memiliki daya prediksi yang tinggi terhadap aliran kas di masa yang akan datang. Laba diyakini oleh para pengguna laporan sebagai alat prediksi yang handal untuk dijadikan dasar dalam mengurangi risiko ketidakpastian arus kas di masa depan. Perusahaan yang memperoleh laba pada periode berjalan selain akan menambah arus kas yang diterima perusahaan pada periode tersebut juga akan mempengaruhi kemampuan perusahaan untuk meningkatkan arus kas di masa depan. Oleh sebab itu, informasi laba dapat memberikan informasi yang berguna bagi para 
pengguna laporan keuangan untuk menilai kinerja perusahaan serta untuk memprediksi arus kas yang akan diterima perusahaan di masa depan.

Cash Flow From Operations. Menurut Reeve, et al. (2007: 692) cash flow from operations diperoleh dari aktivitas utama suatu perusahaan yang umumnya berasal dari transaksi dan peristiwa yang dapat mempengaruhi penetapan laba atau rugi bersih. Arus kas dari aktivitas operasi merupakan arus kas masuk dan arus kas keluar bersih yang berasal dari kegiatan operasi perusahaan. Menurut Ikatan Akuntan Indonesia (2012: 2.3) dalam PSAK No. 2 paragraf 12:

"Jumlah arus kas yang berasal dari aktivitas operasi merupakan indikator utama untuk menentukan apakah operasi perusahaan dapat menghasilkan arus kas yang cukup untuk melunasi pinjaman, memelihara kemampuan operasi perusahaan, dan melakukan investasi baru tanpa mengandalkan sumber pendanaan dari luar. Informasi tentang unsur tertentu arus kas historis, bersama dengan informasi lain, berguna dalam memprediksi arus kas operasi masa depan."

Menurut Ikatan Akuntan Indonesia (2012: 2.3) beberapa contoh arus kas masuk dan kas keluar dari aktivitas operasi antara lain berasal dari: (1) Penerimaan kas dari penjualan barang dan jasa, (2) Penerimaan kas dari royalti, fees, komisi, dan pendapatan lain, (3) Pembayaran kas kepada pemasok barang dan jasa, (4) Pembayaran kas kepada karyawan, (5) Penerimaan dan pembayaran kas oleh perusahaan asuransi sehubungan dengan premi, klaim, anuitas, dan manfaat asuransi lainnya, (6) Pembayaran kas atau penerimaan kembali (restitusi) pajak penghasilan kecuali jika dapat diidentifikasikan secara khusus sebagai bagian dari aktivitas pendanaan dan investasi, (7) Penerimaan dan pembayaran kas dari kontrak yang diadakan untuk tujuan transaksi usaha dan perdagangan. Informasi tentang arus kas suatu perusahaan dapat digunakan oleh para pengguna laporan keuangan sebagai dasar untuk menilai kemampuan perusahaan dalam menghasilkan kas dan setara kas untuk memenuhi kewajibannya dalam membayar dividen, melunasi pinjaman, serta untuk menjalankan dan mengembangkan kegiatan operasional perusahaan. Selain itu, informasi ini juga dapat digunakan untuk memperkirakan jumlah, waktu, dan kepastian arus kas di masa depan yang berguna untuk mengurangi ketidakpastian ekonomi serta untuk mengetahui kondisi perusahaan di masa kini maupun di masa mendatang.

Menurut Yuwana dan Christiawan (2014: 4) arus kas operasi menjadi perhatian penting para pengguna laporan mengingat bahwa dalam jangka panjang suatu perusahaan harus menghasilkan arus kas bersih yang positif dari aktivitas operasi demi kelangsungan hidup perusahaannya. Apabila pada periode berjalan arus kas bersih yang berasal dari aktivitas operasi menunjukkan angka yang positif, maka ini menggambarkan bahwa perusahaan mampu menghasilkan kas untuk memenuhi kebutuhan operasinya, sehingga dapat diperkirakan perusahaan juga akan mampu untuk menciptakan arus kas yang positif di masa depan. Sebaliknya, apabila pada periode berjalan arus kas bersih yang berasal dari aktivitas operasi menunjukkan angka yang negatif, maka ini menggambarkan bahwa perusahaan tidak mampu menghasilkan kas yang cukup untuk memenuhi kebutuhan operasinya dan mengindikasikan bahwa perusahaan akan mengalami kesulitan keuangan di masa mendatang. Informasi mengenai arus kas ini dapat menggambarkan bagaimana kemampuan perusahaan dalam menghasilkan kas di periode berjalan sekaligus dapat 
membantu para pengguna laporan untuk memprediksi kemampuan perusahaan dalam menghasilkan arus kas di masa depan.

Working Capital From Operations. Modal kerja bersih (net working capital) menurut Gitman dan Zutter (2012: 601) didefinisikan sebagai selisih antara current asset dengan current liabilities, sedangkan modal kerja dari operasi (working capital from operations) adalah dana yang diperlukan oleh perusahaan untuk memenuhi aktivitas operasional sehari-hari yang diperoleh dengan menambahkan arus kas operasi dengan modal kerja bersih. Perusahaan harus memiliki modal kerja dari operasi yang cukup agar dapat membiayai aktivitas operasionalnya dan terhindar dari kesulitan keuangan. Pengendalian jumlah modal kerja yang tepat akan menjamin kontinuitas operasi perusahaan secara efisien dan ekonomis. Apabila modal kerja operasi yang dimiliki perusahaan terlalu besar, maka akan terjadi idle fund. Akan tetapi perusahaan yang memiliki modal kerja operasi yang terlalu kecil maka akan mengalami kesulitan keuangan dalam membiayai kegiatan operasionalnya dan cenderung harus mencari dana dari pihak luar untuk membiayai aktivitas operasionalnya.

Menurut Santoso (2013: 1581) modal kerja merupakan aspek yang paling penting bagi setiap perusahaan karena modal kerja merupakan faktor penentu berjalannya kegiatan operasional perusahaan dalam jangka pendek. Kegiatan operasional tersebut berpengaruh pada pendapatan yang diperoleh perusahaan. Perusahaan yang mampu menghasilkan nilai tambah atau keuntungan yang berkelanjutan adalah perusahaan yang mampu memanfaatkan modal kerjanya secara efektif dan efisien. Kesalahan atau tidak efektifnya pengelolaan modal kerja dapat menyebabkan menurunnya performa operasional perusahaan. Modal kerja dari operasi dapat menjamin kelangsungan operasi perusahaan di masa mendatang, dapat memperkirakan kemampuan perusahaan dalam memenuhi kewajiban keuangannya sebelum atau pada saat jatuh tempo, serta dapat digunakan untuk memprediksi besarnya arus kas masa depan yang akan digunakan untuk membiayai aktivitas operasinya.

Accrual Components. Menurut Kieso, et al. (2011: 112-113) "Most companies use accrual-basis accounting: They recognize revenue when it is earned and expense in the periode incured, without regard to the time of receipt or payment of cash." Keunggulan teknik pengakuan yang menggunakan basis akrual adalah informasi yang diberikan tidak hanya mengenai transaksi masa lalu yang melibatkan penerimaan dan pembayaran kas, tetapi juga mengenai kemampuan pembayaran kas di masa depan. Perusahaan yang menggunakan basis akrual dapat mengetahui informasi yang akurat mengenai kondisi keuangan perusahaan karena seluruh sumber daya yang dipengaruhi oleh suatu transaksi dicatat bukan pada saat kas dan setara kas diterima atau dikeluarkan, tetapi pada saat terjadinya transaksi tersebut. Alasan bahwa akrual berkaitan dengan arus kas masa depan karena akrual beserta komponennya dapat memberikan informasi mengenai sumber daya suatu perusahaan yang dapat digunakan untuk memprediksi serta mempresentasikan arus kas yang akan diterima di masa depan. Komponen akrual yang dapat digunakan antara lain account receivable, account payable, inventory, beban depresiasi dan amortisasi, serta komponen akrual lainnya.

Menurut Sumiyati dan Ardiani (2011: 17) account receivable timbul ketika perusahaan melakukan penjualan secara kredit. Pembayaran account receivable dari 
pelanggan akan menimbulkan perubahan account receivable. Pada saat perusahaan menerima pelunasan account receivable, maka arus kas masuk akan mengalami penambahan. Menurut Elingga dan Supatmi (2008: 135) semakin tinggi kenaikan account receivable pada periode berjalan, semakin tinggi pula kemungkinan arus kas yang akan diterima perusahaan di masa mendatang.

Menurut Sumiyati dan Ardiani (2011: 19) account payable yang timbul pada waktu lalu merupakan kewajiban perusahaan yang harus dibayar pada waktu yang akan datang, salah satunya dalam bentuk kas. Pembayaran account payable akan berpengaruh pada pengurangan arus kas. Menurut Elingga dan Supatmi (2008: 135) semakin tinggi kenaikan account payable pada periode berjalan, semakin tinggi pula kemungkinan arus kas yang akan dikeluarkan perusahaan di masa mendatang untuk melunasi account payable tersebut.

Pengaruh inventory terhadap arus kas masa depan tampak ketika terjadi perubahan inventory yang mengindikasikan terjadinya penjualan. Menurut Sumiyati dan Ardiani (2011: 18) pada saat perusahaan melakukan penjualan maka terjadi perubahan inventory yang akan mempengaruhi arus kas. Menurut Elingga dan Supatmi (2008: 135) penurunan inventory mengindikasikan adanya kenaikan penjualan dan penjualan akan mempengaruhi arus kas operasi perusahaan pada saat pendapatan ini benar-benar diperoleh oleh perusahaan, sehingga perubahan inventory akan berdampak pada arus kas di masa depan.

Beban depresiasi dan amortisasi memiliki keterkaitan terhadap arus kas masa depan. Menurut Elingga dan Supatmi (2008: 136) biaya perolehan aset berwujud atau tidak berwujud akan dibebankan secara bertahap terhadap barang yang dihasilkan yang kelak akan dijual. Penjualan yang terjadi akan menghasilkan pendapatan bagi perusahaan, yang kelak akan menghasilkan aliran arus kas masuk pada saat pendapatan tersebut diterima, sehingga beban depresiasi dan amortisasi akan berpengaruh terhadap arus kas perusahaan di masa depan. Komponen akrual lainnya merupakan komponen akrual yang diperoleh dengan cara earnings dikurangi dengan cash flow from operations yang ditambahkan dengan perubahan account receivable dan perubahan inventory dan dikurangkan dengan perubahan account payable serta beban depresiasi dan amortisasi.

Penelitian Terdahulu dan Pengembangan Hipotesis. Tanri, et al. (2014) melakukan penelitian terhadap 348 perusahaan selama tahun 2008 sampai dengan tahun 2011 mengenai pengaruh earnings, cash flow from operations, dan accrual components terhadap future cash flow. Hasil penelitian menunjukkan bahwa earnings dan cash flow from operations memiliki pengaruh terhadap future cash flow sedangkan accrual components tidak memiliki pengaruh terhadap future cash flow.

Shubita (2013) melakukan penelitian terhadap 66 perusahaan selama tahun 2005 sampai dengan tahun 2011 mengenai pengaruh earnings, cash flow from operations, dan accrual components terhadap future cash flow. Hasil penelitian menunjukkan bahwa earnings, cash flow from operations, dan accrual components memiliki pengaruh terhadap future cash flow.

Takhtaei dan Karimi (2013) melakukan penelitian terhadap 94 perusahaan selama tahun 2005 sampai dengan tahun 2009 mengenai pengaruh cash flow from operations, earnings, net earnings plus depreciation expense, dan working capital from operations terhadap future cash flow. Hasil penelitian menunjukkan bahwa cash flow from 
operations, earnings, net earnings plus depreciation expense, dan working capital from operations memiliki pengaruh terhadap future cash flow.

Moeinaddin, et al. (2012) melakukan penelitian terhadap 81 perusahaan selama tahun 2006 sampai dengan tahun 2010 mengenai pengaruh cash flow from operations, earnings, net earnings plus depreciation expense, dan working capital from operations terhadap future cash flow. Hasil penelitian menunjukkan bahwa earnings dan net earnings plus depreciation expense memiliki pengaruh terhadap future cash flow sedangkan cash flow from operations dan working capital from operations tidak memiliki pengaruh terhadap future cash flow.

Joni (2011) melakukan penelitian terhadap 42 perusahaan selama tahun 2005 sampai dengan tahun 2009 mengenai pengaruh earnings dan cash flow from operations terhadap future cash flow. Hasil penelitian menunjukkan bahwa earnings dan cash flow from operations memiliki pengaruh terhadap future cash flow.

Yuliafitri (2011) melakukan penelitian terhadap 65 perusahaan selama tahun 2005 sampai dengan tahun 2007 mengenai pengaruh earnings, cash flow from operations, dan dividen kas terhadap future cash flow. Hasil penelitian menunjukkan bahwa dividen kas memiliki pengaruh terhadap future cash flow sedangkan earnings dan cash flow from operations tidak memiliki pengaruh terhadap future cash flow. Berdasarkan uraian di atas maka perumusan hipotesis adalah sebagai berikut:

$\mathrm{Ha}_{1}$ : Earnings memiliki pengaruh terhadap future cash flow.

$\mathrm{Ha}_{2}$ : Cash flow from operations memiliki pengaruh terhadap future cash flow.

$\mathrm{Ha}_{3}$ : Working capital from operations memiliki pengaruh terhadap future cash flow.

$\mathrm{Ha}_{4}$ : Accrual components memiliki pengaruh terhadap future cash flow.

Hubungan antara variabel independen dan variabel dependen dapat digambarkan melalui model penelitian yang dapat dilihat pada gambar 1 .

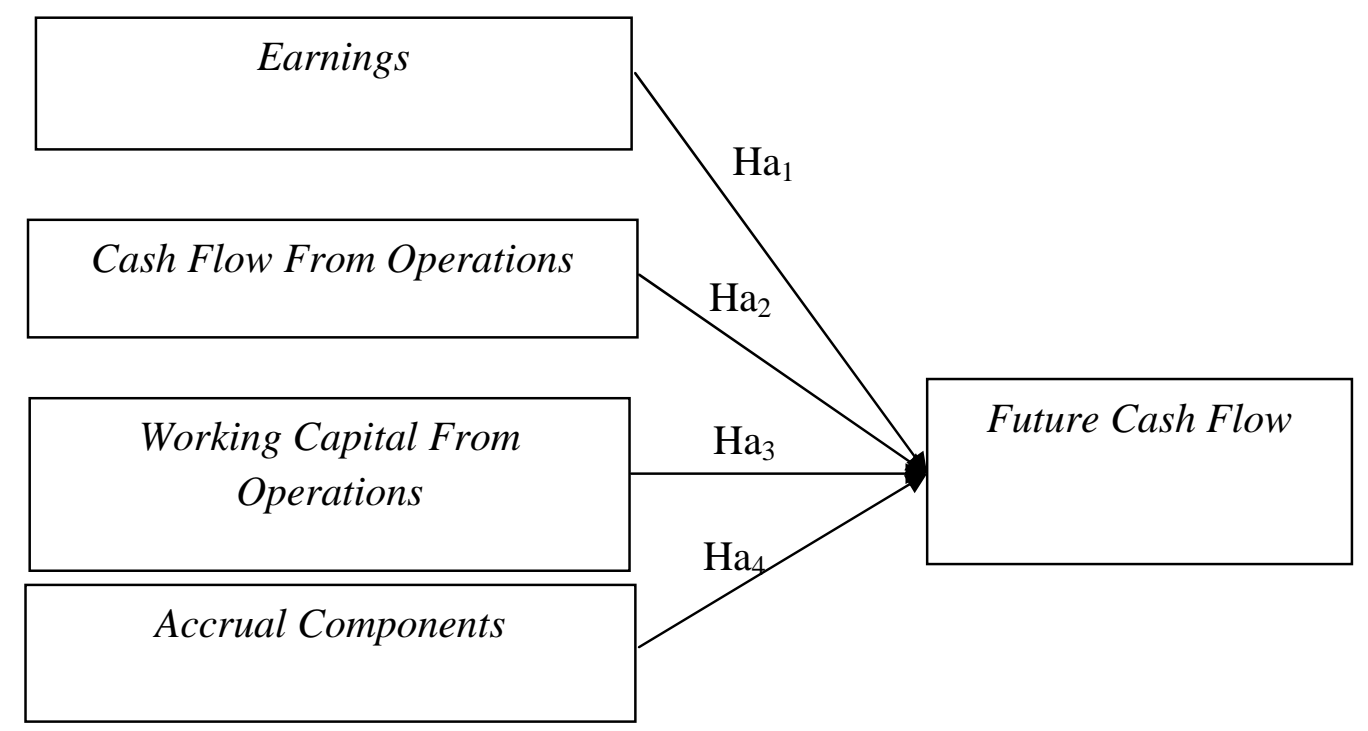

Gambar 1. Model Penelitian 


\section{METODE}

Populasi dan Metode Pengambilan Sampel. Populasi dalam penelitian ini adalah seluruh perusahaan manufaktur yang terdaftar di Bursa Efek Indonesia selama tahun 20102012. Pemilihan sampel menggunakan metode purposive sampling, artinya populasi yang dijadikan sampel merupakan populasi yang memenuhi kriteria yang telah ditentukan. Perusahaan yang akan dijadikan sampel penelitian adalah perusahaan yang memiliki kriteria sebagai berikut: a. Perusahaan mempublikasikan laporan keuangan yang berakhir per tanggal 31 Desember, b. Perusahaan menyajikan laporan keuangan dalam mata uang Rupiah, dan c. Perusahaan tidak mengalami kerugian.

Operasionalisasi Variabel Penelitian. Variabel terikat dalam penelitian ini adalah future cash flow sedangkan variabel bebas dalam penelitian ini terdiri dari earnings, cash flow from operations, working capital from operations, dan accrual components.

Future Cash Flow. Future cash flow yang digunakan dalam penelitian ini adalah jumlah arus kas yang berasal dari aktivitas operasi pada periode setelah satu tahun amatan. Future cash flow diberi simbol $\mathrm{CFO}_{\mathrm{t}+1}$ dan skala pengukuran yang digunakan adalah skala rasio. Sesuai penelitian Takhtaei dan Karimi (2013: 220) future cash flow dihitung dengan rumus:

$\mathrm{CFO}_{\mathrm{t}+1}=$ Cash flow from operations pada periode setelah satu tahun amatan

Earnings. Earnings yang digunakan dalam penelitian ini adalah net income after tax sebelum pos-pos luar biasa pada tahun berjalan. Earnings diberi simbol $E_{A R N_{t}}$ dan skala pengukuran yang digunakan adalah skala rasio. Sesuai penelitian Moeinaddin, et al. (2012: 96) earnings dihitung dengan rumus:

$\mathrm{EARN}_{\mathrm{t}}=$ Net income after tax sebelum pos-pos luar biasa pada tahun berjalan

Cash Flow From Operations. Cash flow from operations yang digunakan dalam penelitian ini adalah jumlah arus kas yang berasal dari aktivitas operasi pada tahun berjalan. Cash flow from operations diberi simbol $\mathrm{CFO}_{\mathrm{t}}$ dan skala pengukuran yang digunakan adalah skala rasio. Sesuai penelitian Moeinaddin, et al. (2012: 96) cash flow from operations dihitung dengan rumus:

$\mathrm{CFO}_{\mathrm{t}}=$ Cash flow from operations pada tahun berjalan

Working Capital From Operations. Working capital from operations yang digunakan dalam penelitian ini adalah dana yang diperlukan oleh perusahaan untuk memenuhi aktivitas operasional sehari-hari yang diperoleh dengan menambahkan arus kas operasi dengan modal kerja bersih. Working capital from operations diberi simbol $\mathrm{WCFO}_{\mathrm{t}}$ dan skala pengukuran yang digunakan adalah skala rasio. Sesuai penelitian Takhtaei dan Karimi (2013: 220) working capital from operations dihitung dengan rumus:

$$
\mathrm{WCFO}_{\mathrm{t}}=\mathrm{CFO}_{t}+\mathrm{NWC}
$$

Keterangan: $\mathrm{WCFO}_{\mathrm{t}}$ : Working capital from operations pada tahun berjalan; $\mathrm{CFO}_{t}$ : Cash flow from operations pada tahun berjalan; NWC : Net working capital;

Rumus yang diperlukan dalam menghitung net working capital adalah sebagai berikut: 


\section{$\mathrm{NWC}=\Delta$ Current Asset $-\Delta$ Current Liabilities}

Keterangan: NWC : Net working capital ; $\Delta$ Current Asset : Current asset tahun berjalan current asset tahun sebelumnya; $\Delta$ Current Liabilities : Current liabilities tahun berjalan - current liabilities tahun sebelumnya

Accrual Components. Accrual components yang digunakan dalam penelitian ini adalah perubahan piutang dagang ( $\Delta$ account receivable), perubahan hutang dagang ( $\Delta$ account payable), perubahan persediaan ( $\Delta$ inventory), beban depresiasi dan amortisasi (depreciation dan amortization expense), dan komponen akrual lainnya (other accrual components). Accrual components diberi simbol ACC dan skala pengukuran yang digunakan adalah skala rasio. Sesuai penelitian Shubita (2013: 433) accrual components dihitung dengan rumus:

$$
\mathrm{ACC}=\mathrm{CFO}_{\mathrm{t}}+\Delta \mathrm{A} / \mathrm{R}_{\mathrm{it}-1}+\Delta \mathrm{A} / \mathrm{P}_{\mathrm{it}-1}+\Delta \mathrm{INV}_{\mathrm{it}-1}+\text { Depre dan Amor }{ }_{\mathrm{t}}+\text { Others }
$$

Keterangan:ACC : Accrual components; $\mathrm{CFO}_{\mathrm{t}}$ : Cash flow from operations pada tahun berjalan; $\Delta \mathrm{A} / \mathrm{R}_{\mathrm{it}-1}$ : Account receivable tahun berjalan - account receivable tahun sebelumnya; $\Delta \mathrm{A} / \mathrm{P}_{\mathrm{it}-1}$ : Account payable tahun berjalan - account payable tahun sebelumnya; $\Delta \mathrm{INV}_{\mathrm{it}-1}$ : Inventory tahun berjalan - inventory tahun sebelumnya; Depre dan Amor $_{\mathrm{t}}$ : Depreciation and amortization expense pada tahun berjalan; Others: Other accrual components;

Rumus yang digunakan untuk menghitung other accrual components:

Others $=\mathrm{EARN}_{\mathrm{t}}-\left(\mathrm{CFO}_{\mathrm{t}}+\Delta \mathrm{A} / \mathrm{R}_{\mathrm{it}-1}+\Delta \mathrm{INV}_{\mathrm{it}-1}-\Delta \mathrm{A} / \mathrm{P}_{\mathrm{it}-1}-\right.$ Depre dan Amor $\left._{\mathrm{t}}\right)$

Keterangan: EARN $\mathrm{N}_{\mathrm{t}}$ : Net income after tax sebelum pos-pos luar biasa pada tahun berjalan

Teknik Pengumpulan Data. Obyek penelitian ini adalah pengaruh earnings, cash flow from operations, working capital from operations, dan accrual components terhadap future cash flow pada perusahaan manufaktur yang terdaftar di Bursa Efek Indonesia selama tahun 2010-2012. Data yang digunakan dalam penelitian ini adalah data sekunder yang berasal dari Bursa Efek Indonesia berupa laporan keuangan dan laporan tahunan emiten selama tahun 2010-2012 yang diperoleh dari website www.idx.co.id. Data yang diperoleh kemudian diolah dan diuji dengan menggunakan bantuan program software Statistical Product and Service Solution (SPSS) for Windows.

Teknik Pengolahan Data. Analisis yang dilakukan dalam penelitian ini adalah analisis yang bersifat kuantitatif, dengan menggunakan analisis regresi Ordinary Least Square. Sebelum dilakukan semua pengujian, langkah awal adalah melakukan beberapa pengujian asumsi klasik terhadap data yang dikumpulkan, karena model regresi Ordinary Least Square mengandung beberapa asumsi klasik yang harus dipenuhi. Model regresi dalam penelitian ini adalah: $\mathrm{CFO}_{\mathrm{t}+1}=\mathrm{a}+\mathrm{b}_{1} \mathrm{EARN}_{\mathrm{t}}+\mathrm{b}_{2} \mathrm{CFO}_{\mathrm{t}}+\mathrm{b}_{3} \mathrm{WCFO}_{\mathrm{t}}+\mathrm{b}_{4} \mathrm{ACC}_{\mathrm{t}}+\mathrm{e}$

Keterangan: $\mathrm{CFO}_{\mathrm{t}+1}$ : Cash flow from operations pada periode setelah satu tahun amatan; EARN $_{\mathrm{t}}$ : Net income after tax sebelum pos-pos luar biasa pada tahun berjalan; $\mathrm{CFO}_{\mathrm{t}}$ : Cash flow from operations pada tahun berjalan; $\mathrm{WCFO}_{\mathrm{t}}$ : Working capital from operations 
pada tahun berjalan; ACC : Accrual components; a : Nilai intersep atau konstanta; $\mathrm{b}_{1,2,3,4}$ : Koefisien regresi parsial; e : Residual term

Setelah semua uji asumsi klasik yaitu normalitas, heteroskedastisitas, multikolinieritas, dan autokorelasi terpenuhi, langkah berikutnya adalah menguji hipotesis penelitian apakah variabel independen dapat digunakan untuk memprediksi variabel dependen. Untuk itu dilakukan uji statistik dengan menggunakan uji $F$ (uji secara bersama-sama) maupun uji t (uji secara parsial). Penelitian ini menggunakan tingkat kesalahan sebesar 5\%.

\section{HASIL DAN PEMBAHASAN}

Pemilihan Sampel. Populasi dalam penelitian ini adalah seluruh perusahaan manufaktur yang terdaftar di Bursa Efek Indonesia selama tahun 2010-2012. Perusahaan yang akan dijadikan sampel penelitian adalah perusahaan yang memiliki kriteria sebagai berikut: a. Perusahaan mempublikasikan laporan keuangan yang berakhir per tanggal 31 Desember, b. Perusahaan menyajikan laporan keuangan dalam mata uang Rupiah, dan c. Perusahaan tidak mengalami kerugian. Berdasarkan kriteria tersebut diperoleh sampel sebanyak 165 data.

Statistik Deskriptif. Statistik deskriptif digunakan untuk memberikan gambaran nilai minimum, nilai maksimum, nilai rata-rata, dan standar deviasi dari variabel yang diteliti yaitu future cash flow, earnings, cash flow from operations, working capital from operations, dan accrual components.

Tabel 1. Statistik Deskriptif

\begin{tabular}{lrrrrr}
\hline & $N$ & \multicolumn{1}{c}{ Minimum } & \multicolumn{1}{c}{ Maximum } & \multicolumn{1}{c}{ Mean } & \multicolumn{1}{c}{ Std. Deviation } \\
\hline EARN $_{t}$ & 165 & 306.286 .065 & 635.176 .093 .653 & $79.763 .592 .792,267$ & $103.459 .525 .248,9377$ \\
CFO $_{t}$ & 165 & -206.699 .334 .647 & 635.028 .604 .390 & $76.311 .167 .769,091$ & $126.695 .609 .541,4057$ \\
WCFO $_{t}$ & 165 & -299.855 .279 .030 & 779.712 .753 .751 & $93.729 .338 .944,891$ & $144.020 .442 .473,0575$ \\
ACC & 165 & -235.818 .761 .053 & 1.094 .228 .703 .786 & $167.455 .599 .810,449$ & $197.302 .299 .910,0927$ \\
CFO $_{t+1}$ & 165 & -142.720 .644 .791 & 635.028 .604 .390 & $88.683 .144 .206,903$ & $135.329 .912 .485,5182$ \\
\hline
\end{tabular}

Berdasarkan Tabel 1 nilai minimum untuk earnings sebesar 306.286.065, nilai minimum untuk cash flow from operations sebesar -206.699.334.647, nilai minimum untuk working capital from operations sebesar -299.855.279.030, nilai minimum untuk accrual components sebesar -235.818.761.053, dan nilai minimum untuk future cash flow sebesar -142.720.644.791. Nilai maksimum untuk earnings sebesar 635.176.093.653, nilai maksimum untuk cash flow from operations sebesar 635.028.604.390, nilai maksimum untuk working capital from operations sebesar 779.712.753.751, nilai maksimum untuk accrual components sebesar 1.094.228.703.786, dan nilai maksimum untuk future cash flow sebesar 635.028.604.390.

Nilai rata-rata untuk earnings sebesar 79.763.592.792,267 dengan standar deviasi sebesar 103.459.525.248,9377. Nilai rata-rata untuk cash flow from operations sebesar 76.311.167.769,091 dengan standar deviasi sebesar 126.695.609.541,4057. Nilai rata-rata untuk working capital from operations sebesar 93.729.338.944,891 dengan standar deviasi 
sebesar 144.020.442.473,0575. Nilai rata-rata untuk accrual components sebesar 167.455.599.810,449 dengan standar deviasi sebesar 197.302.299.910,0927. Nilai rata-rata untuk future cash flow sebesar 88.683.144.206,903 dengan standar deviasi sebesar 135.329.912.485,5182.

Hasil Uji Kualitas Data. Penelitian ini menggunakan uji normalitas dalam menguji kualitas data. Hasil pengujian normalitas dengan menggunakan One-Sample KolmogorovSmirnov Test adalah sebagai berikut:

Tabel 2. Hasil Uji Normalitas

\begin{tabular}{ccc}
\hline Keterangan & $\mathrm{N}$ & Asymp. Sig (2-tailed) \\
\hline Unstandardized Residual & 165 & 0,120 \\
\hline
\end{tabular}

Tabel 2. menunjukkan nilai asymp. sig (2-tailed) sebesar 0,120 dimana nilai ini lebih besar dari 0,05 sehingga dapat disimpulkan bahwa residual data berdistribusi normal.

Hasil Uji Asumsi Klasik. Uji Heteroskedastisitas. Hasil pengujian heteroskedastisitas dengan menggunakan uji Koefisien Korelasi Peringkat Spearman (Rank Spearman test) adalah sebagai berikut:

Tabel 3. Hasil Uji Heteroskedastisitas

\begin{tabular}{|c|c|c|c|c|c|c|c|}
\hline & & & $E A R N_{t}$ & $\mathrm{CFO}_{t}$ & $W C F O_{t}$ & $A C C$ & $\begin{array}{c}\text { Unstandardized } \\
\text { Residual } \\
\end{array}$ \\
\hline \multirow[t]{15}{*}{$\begin{array}{l}\text { Spearman's } \\
\text { rho }\end{array}$} & $E A R N_{t}$ & $\begin{array}{l}\text { Correlation } \\
\text { Coefficient }\end{array}$ & 1,000 & $0,715_{*}^{*}$ & $0,795^{* * *}$ & $0,754^{*}$ & 0,073 \\
\hline & & Sig. (2-tailed) & & 0,000 & 0,000 & 0,000 & 0,350 \\
\hline & & $N$ & 165 & 165 & 165 & 165 & 165 \\
\hline & $C F O_{t}$ & $\begin{array}{l}\text { Correlation } \\
\text { Coefficient }\end{array}$ & $0,715^{*}$ & 1,000 & $0,698^{* *}$ & $0,706_{*}^{*}$ & 0,068 \\
\hline & & Sig. (2-tailed) & 0,000 & & 0,000 & 0,000 & 0,383 \\
\hline & & $N$ & 165 & 165 & 165 & 165 & 165 \\
\hline & $W C F O_{t}$ & $\begin{array}{l}\text { Correlation } \\
\text { Coefficient }\end{array}$ & $0,795^{*}$ & $0,698_{*}^{*}$ & 1,000 & $0,600^{*}$ & 0,104 \\
\hline & & Sig. (2-tailed) & 0,000 & 0,000 & & 0,000 & 0,184 \\
\hline & & $N$ & 165 & 165 & 165 & 165 & 165 \\
\hline & $A C C$ & $\begin{array}{l}\text { Correlation } \\
\text { Coefficient }\end{array}$ & $0,754^{*}$ & $0,706_{*}^{*}$ & $0,600^{* *}$ & 1,000 & 0,070 \\
\hline & & Sig. (2-tailed) & 0,000 & 0,000 & 0,000 & & 0,370 \\
\hline & & $N$ & 165 & 165 & 165 & 165 & 165 \\
\hline & $\begin{array}{l}\text { Unstandardized } \\
\text { Residual }\end{array}$ & $\begin{array}{l}\text { Correlation } \\
\text { Coefficient }\end{array}$ & 0,073 & 0,068 & 0,104 & 0,070 & 1,000 \\
\hline & & Sig. (2-tailed) & 0,350 & 0,383 & 0,184 & 0,370 & \\
\hline & & $N$ & 165 & 165 & 165 & 165 & 165 \\
\hline
\end{tabular}

**. Correlation is significant at the 0.01 level (2-tailed).

Tabel 3 menunjukkan bahwa earnings, cash flow from operations, working capital from operation, dan accrual components memiliki nilai signifikansi lebih besar dari 0,05 sehingga dapat disimpulkan bahwa pada model regresi tidak terjadi heteroskedastisitas. 
Uji Multikolinieritas. Hasil pengujian multikolinieritas adalah sebagai berikut:

Tabel 4. Hasil Uji Multikolinieritas

\begin{tabular}{lccc}
\hline \multicolumn{1}{c}{ Variabel } & Tolerance & VIF & Kesimpulan \\
\hline EARN $_{\mathrm{t}}$ & 0,150 & 6,652 & Tidak terjadi multikolinieritas \\
$\mathrm{CFO}_{\mathrm{t}}$ & 0,212 & 4,715 & Tidak terjadi multikolinieritas \\
$\mathrm{WCFO}_{\mathrm{t}}$ & 0,219 & 4,556 & Tidak terjadi multikolinieritas \\
$\mathrm{ACC}$ & 0,288 & 3,474 & Tidak terjadi multikolinieritas \\
\hline
\end{tabular}

Tabel 4 menunjukkan bahwa earnings, cash flow from operations, working capital from operation, dan accrual components memiliki nilai Tolerance di atas 0,1 dan nilai Variance Inflation Factor (VIF) di bawah 10 sehingga dapat disimpulkan bahwa pada model regresi tidak terjadi multikolinieritas.

Uji Autokorelasi. Hasil pengujian autokorelasi dengan menggunakan uji Durbin Watson adalah sebagai berikut:

Tabel 5. Hasil Uji Autokorelasi

\begin{tabular}{cc}
\hline Keterangan & Nilai \\
\hline Durbin Watson & 2,1060 \\
dl (tabel D-W) & 1,6960 \\
du (tabel D-W) & 1,7953 \\
4-du & 2,2047 \\
4-dl & 2,3040 \\
\hline
\end{tabular}

Tabel 5 menunjukkan bahwa nilai Durbin Watson sebesar 2,1060. Nilai tersebut berada di antara du dan 4-du sehingga dapat disimpulkan bahwa pada model regresi tidak terjadi autokorelasi.

Model Regresi. Setelah semua uji asumsi klasik terpenuhi, langkah berikutnya adalah melakukan pengujian hipotesis terhadap model regresi. Tujuan analisis ini adalah untuk mengetahui pengaruh earnings, cash flow from operations, working capital from operations, dan accrual components terhadap future cash flow pada perusahaan manufaktur yang terdaftar di Bursa Efek Indonesia selama tahun 2010-2012.

Tabel 6. Model Regresi

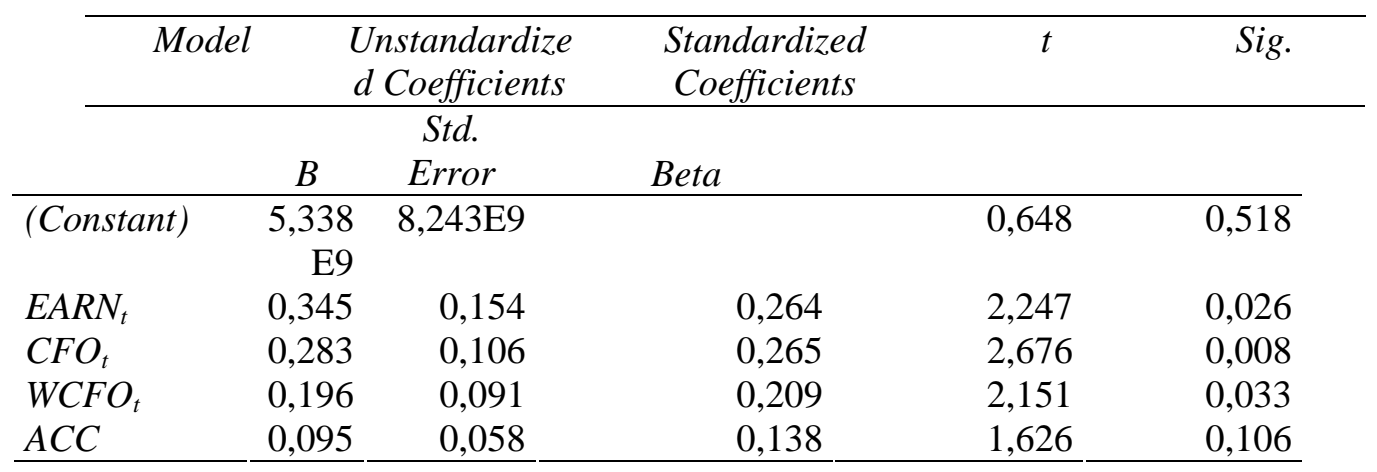


Model regresi yang diperoleh adalah: $\mathrm{CFO}_{\mathrm{t}+1}=5,338 \mathrm{E} 9+0,345 \mathrm{EARN}_{\mathrm{t}}+0,283 \mathrm{CFO}_{\mathrm{t}}+$ $0,196 \mathrm{WCFO}_{\mathrm{t}}+0,095 \mathrm{ACC}+\mathrm{e}$

Tabel 7. Hasil Uji F

\begin{tabular}{lcrccc}
\hline \multicolumn{1}{c}{ Model } & Sum of Squares & $d f$ & Mean Square & $F$ & Sig. \\
\hline Regression & $2,008 \mathrm{E} 24$ & 4 & $5,019 \mathrm{E} 23$ & & \\
Residual & $9,958 \mathrm{E} 23$ & 160 & 6,224E21 & 80,648 & 0,000 \\
Total & 3,004E24 & 164 & & & \\
\hline
\end{tabular}

Tabel 7 menunjukkan nilai signifikansi sebesar 0,000 dimana nilai ini lebih kecil dari 0,05. Ini berarti Ho ditolak dan dapat disimpulkan bahwa paling sedikit terdapat satu variabel independen yang mempengaruhi future cash flow. Dengan demikian uji t (uji secara parsial) untuk menjawab hipotesis penelitian dapat dilakukan untuk mengetahui variabel independen mana saja yang mempengaruhi future cash flow.

Pengujian Hipotesis. Hasil uji t adalah sebagai berikut:

Tabel 8. Hasil Uji t

\begin{tabular}{llclrl}
\hline Model & B & Standard Error & t & Sig. & Kesimpulan \\
\hline EARN $_{\mathrm{t}}$ & 0,345 & 0,154 & 2,247 & 0,026 & $\mathrm{Ha}_{1}$ tidak ditolak \\
CFO $_{\mathrm{t}}$ & 0,283 & 0,106 & 2,676 & 0,008 & $\mathrm{Ha}_{2}$ tidak ditolak \\
WCFO $_{\mathrm{t}}$ & 0,196 & 0,091 & 2,151 & 0,033 & $\mathrm{Ha}_{3}$ tidak ditolak \\
ACC & 0,095 & 0,058 & 1,626 & 0,106 & $\mathrm{Ha}_{4}$ ditolak \\
\hline
\end{tabular}

Uji Hipotesis Pertama. Hipotesis alternatif pertama $\left(\mathrm{Ha}_{1}\right)$ dalam penelitian ini adalah earnings memiliki pengaruh terhadap future cash flow. Tabel 8. menunjukkan bahwa nilai signifikansi earnings adalah sebesar 0,026 dimana nilai ini lebih kecil dari 0,05 sehingga dapat disimpulkan bahwa $\mathrm{Ha}_{1}$ tidak ditolak atau dengan kata lain earnings memiliki pengaruh terhadap future cash flow. Hasil penelitian ini konsisten dengan penelitian Takhtaei dan Karimi (2013), Moeinaddin, et al. (2012), serta Joni (2011) tetapi tidak konsisten dengan penelitian Yuliafitri (2011). Earnings memiliki koefisien regresi positif artinya terjadi hubungan yang positif antara earnings dengan future cash flow. Semakin tinggi nilai earnings maka semakin tinggi nilai future cash flow. Perusahaan yang memperoleh laba pada periode berjalan selain akan menambah arus kas operasi yang diterima perusahaan pada periode tersebut juga akan mempengaruhi kemampuan perusahaan untuk meningkatkan arus kas di masa depan, sehingga informasi laba dapat memberikan informasi yang berguna bagi para pengguna laporan keuangan untuk menilai kinerja perusahaan serta untuk memprediksi arus kas yang akan diterima perusahaan di masa depan.

Uji Hipotesis Kedua. Hipotesis alternatif kedua $\left(\mathrm{Ha}_{2}\right)$ dalam penelitian ini adalah cash flow from operations memiliki pengaruh terhadap future cash flow. Tabel 8. menunjukkan bahwa nilai signifikansi cash flow from operations adalah sebesar 0,008 dimana nilai ini lebih kecil dari 0,05 sehingga dapat disimpulkan bahwa $\mathrm{Ha}_{2}$ tidak ditolak atau dengan kata 
lain cash flow from operations memiliki pengaruh terhadap future cash flow. Hasil penelitian ini konsisten dengan penelitian Takhtaei dan Karimi (2013) serta Joni (2011) tetapi tidak konsisten dengan penelitian Moeinaddin, et al. (2012) serta Yuliafitri (2011). Cash flow from operations memiliki koefisien regresi positif artinya terjadi hubungan yang positif antara cash flow from operations dengan future cash flow. Semakin tinggi nilai cash flow from operations maka semakin tinggi nilai future cash flow. Arus kas yang diterima perusahaan merupakan selisih antara arus kas masuk dan arus kas keluar yang hanya berasal dari kegiatan operasi perusahaan. Arus kas yang diperoleh dari aktivitas operasi inilah yang nantinya akan menggambarkan kemampuan perusahaan dalam menghasilkan kas dan setara kas yang akan digunakan untuk membiayai kegiatan operasional perusahaan sehari-hari, melunasi pinjaman, serta melakukan investasi baru tanpa mengandalkan sumber pendanaan dari luar. Perusahaan yang mampu menghasilkan arus kas bersih yang positif pada periode berjalan, berarti perusahaan tersebut mampu menghasilkan kas untuk memenuhi kebutuhan operasinya sehingga diperkirakan bahwa perusahaan juga akan mampu untuk menciptakan arus kas yang positif di masa depan.

Uji Hipotesis Ketiga. Hipotesis alternatif ketiga $\left(\mathrm{Ha}_{3}\right)$ dalam penelitian ini adalah working capital from operations memiliki pengaruh terhadap future cash flow. Tabel 8. menunjukkan bahwa nilai signifikansi working capital from operations adalah sebesar 0,033 dimana nilai ini lebih kecil dari 0,05 sehingga dapat disimpulkan bahwa $\mathrm{Ha}_{3}$ tidak ditolak atau dengan kata lain working capital from operations memiliki pengaruh terhadap future cash flow. Hasil penelitian ini konsisten dengan penelitian Takhtaei dan Karimi (2013) tetapi tidak konsisten dengan penelitian Moeinaddin, et al. (2012). Working capital from operations memiliki koefisien regresi positif artinya terjadi hubungan yang positif antara working capital from operations dengan future cash flow. Semakin tinggi nilai working capital from operations maka semakin tinggi nilai future cash flow. Perusahaan harus memiliki modal kerja operasi yang cukup agar dapat membiayai aktivitas operasionalnya dan terhindar dari kesulitan keuangan. Pengendalian jumlah modal kerja yang tepat akan menjamin kontinuitas operasi perusahaan secara efisien dan ekonomis. Jika perusahaan mampu menghasilkan modal kerja operasi yang positif maka kelangsungan operasinya dapat terjamin, sehingga perusahaan dapat mengelola aktivitas operasionalnya dengan baik dan mampu menghasilkan arus kas yang positif di masa yang akan datang.

Uji Hipotesis Keempat. Hipotesis alternatif keempat $\left(\mathrm{Ha}_{4}\right)$ dalam penelitian ini adalah accrual components memiliki pengaruh terhadap future cash flow. Tabel 8. menunjukkan bahwa nilai signifikansi accrual components adalah sebesar 0,106 dimana nilai ini lebih besar dari 0,05 sehingga dapat disimpulkan bahwa $\mathrm{Ha}_{4}$ ditolak atau dengan kata lain accrual components tidak memiliki pengaruh terhadap future cash flow. Hasil penelitian ini konsisten dengan penelitian Tanri, et al. (2014) tetapi tidak konsisten dengan penelitian Shubita (2013). 


\section{PENUTUP}

Simpulan. Earnings memiliki pengaruh terhadap future cash flow. Hasil penelitian ini konsisten dengan penelitian Takhtaei dan Karimi (2013), Moeinaddin, et al. (2012), serta Joni (2011) tetapi tidak konsisten dengan penelitian Yuliafitri (2011). Cash flow from operations memiliki pengaruh terhadap future cash flow. Hasil penelitian ini konsisten dengan penelitian Takhtaei dan Karimi (2013) serta Joni (2011) tetapi tidak konsisten dengan penelitian Moeinaddin, et al. (2012) serta Yuliafitri (2011).

Working capital from operations memiliki pengaruh terhadap future cash flow. Hasil penelitian ini konsisten dengan penelitian Takhtaei dan Karimi (2013) tetapi tidak konsisten dengan penelitian Moeinaddin, et al. (2012). Accrual components tidak memiliki pengaruh terhadap future cash flow. Hasil penelitian ini konsisten dengan penelitian Tanri, et al. (2014) tetapi tidak konsisten dengan penelitian Shubita (2013).

Penelitian ini hanya dilakukan pada 165 perusahaan manufaktur yang terdaftar di Bursa Efek Indonesia selama tahun 2010-2012. Sebaiknya penelitian selanjutnya memperpanjang periode pengamatan dan menguji faktor-faktor lain yang diperkirakan memiliki pengaruh terhadap future cash flow tapi belum diuji pada penelitian ini.

\section{DAFTAR RUJUKAN}

Elingga, Muna dan Supatmi. (2008) "Pengaruh komponen akuntansi akrual sebagai prediktor arus kas operasi pada saat krisis dan setelah krisis". Jurnal Akuntansi. (2). Mei. hal. 132-141

Gitman, Lawrence J. dan Chad J. Zutter. (2012) Principles of managerial finance. Edisi 13. United States: Pearson

Ikatan Akuntan Indonesia. (2012) Standar akuntansi keuangan. Jakarta: Salemba Empat

Joni. (2011) "Daya prediksi laba dan aliran kas (studi empiris pada perusahaan manufaktur di bursa efek indonesia periode 2005-2009)". Jurnal Reviu Akuntansi dan Keuangan. 1. (1). April. hal. 39-48

Kieso, Donald E., Jerry J. Weygandt, dan Terry D. Warfield. (2011) Intermediate accounting. Edisi IFRS. 1. United States: John Wiley \& Sons

Moeinaddin, Mahmood, Saeid S. Ardakani, dan Fatemeeh Akhoondzadeh. (2012) Examination the ability of earning and cash flow in predicting future cash flow. Interdisciplinary Journal of Contemporary Research in Business. 4. (6). Oktober. hal. 94-101

Pratiwi, Endah Panca. (2010) "Analisis kemampuan prediktif laba dan arus kas operasi dalam memprediksi arus kas operasi masa depan". Jurnal Ekonomi. 18. (3). Mei. hal. $1-15$

Reeve, James M., Carl Warren, dan Jonathan Duchac. (2007) Principles of accounting. Edisi 22. United States: John Wiley \& Sons

Santoso, Clairene E. E. (2013) "Perputaran modal kerja dan perputaran piutang pengaruhnya terhadap profitabilitas pada PT PEGADAIAN (PERSERO)". Jurnal EMBA. 1. (4). Desember. hal. 1581-1590

Shubita, Mohammad Fawzi. (2013) "Accruals and cash flow- A case of Jordan". Interdisciplinary Journal of Contemporary Research in Business. 5. (3). Juli. hal. 428-441 
Sumiyati dan Ika S. Ardiani (2011) "Komponen akuntansi akrual sebagai prediktor arus kas operasi (studi kasus pada perusahaan industri farmasi di BEJ tahun 20052008)". Jurnal Solusi. 10. (2). April. hal. 48-58

Takhtaei, Nasrollah dan Hasan Karimi. (2013) "Relative ability of earnings data and cash flow in predicting future cash flow". International Journal of Accounting and Financial Reporting. 3. (1). hal. 214-226

Tanri, Jessica, Yuliawati Tan, dan Aurelia C. Sutanto. (2014) "Kemampuan earnings, cash flow from operation dan komponen accruals memprediksi future cash flow from operation pada badan usaha sektor manufaktur yang terdaftar di BEI periode 2008-2011". Jurnal Ilmiah Mahasiswa Universitas Surabaya. 3. (1). hal. 1-19

Wanti, Ferra Kusuma Purbo. (2012) "Kemampuan laba bersih, arus kas operasi, dan rasio piutang untuk mempengaruhi arus kas masa mendatang pada perusahaan food and beverage di BEI". Berkala Ilmiah Mahasiswa Akuntansi. 1. (3). Mei. hal. 3641

Yuliafitri, Indri. (2011) "Analisis faktor-faktor yang mempengaruhi laba dan arus kas masa depan pada perusahaan go publik". Jurnal Investasi. 7. (1). hal. 14-30

Yuwana, Vina dan Yulius Jogi Christiawan. (2014) "Analisa kemampuan laba dan arus kas operasi dalam memprediksi arus kas operasi masa depan". Business Accounting Review. 2. (1). hal. 1-10 